\title{
Effects of sleep state and feeding on cranial blood flow of the human neonate
}

\author{
P M RAHILLY \\ Neonatal Research Unit, Department of Physiology, The London Hospital Medical College
}

SUMMARY Jugular venous occlusion plethysmography was performed on sleeping babies. Cranial blood flow (CBF) was calculated by correcting for noncompressible drainage pathways. Sleep state of the baby was monitored using clinical and EEG criteria. In 20 babies CBF was consistently higher in rapid eye movement (REM) sleep compared with nonREM sleep (mean difference $24 \cdot 2 \%$ ). In 7 babies systolic blood pressure was consistently higher in REM sleep (mean 20.2\%). There was no correlation between the degree of change in blood pressure and CBF. In 11 babies in whom CBF was measured at known times after feeding, there was a consistently lower flow rate during the first hour compared with 2 hours later (mean difference $34.5 \%$ ). The degree of change was unrelated to amount of feed taken, despite the method of test weighing being demonstrably accurate.

The introduction of jugular occlusion plethysmography $^{1-2}$ with improved analysis ${ }^{3}$ has made the measurement of cranial blood flow (CBF) in the healthy neonate feasible and ethically acceptable. Preliminary studies by Milligan (D Milligan, 1979, personal communication) and Dear ${ }^{39}$ have shown that jugular flow, and therefore probably CBF, are altered by sleep states and feeding. The existence of different sleep states was recognised by Galen ${ }^{4}$ and by the ancient Hindu philosophers. ${ }^{5}$ There have been various clinical and EEG classifications. ${ }^{6-11}$ Confusion has been caused by ignoring species difference and placing too much emphasis on the concept of 'depth' of sleep..$^{12}$ Rapid eye movement (REM) sleep, compared with nonREM sleep, is a paradoxical state, accompanied by highly labile physiological functions, ${ }^{12}$ it is probably present before birth, ${ }^{13}$ and predominates in the newborn slowly decreasing with age. 11 14 41-42 Cerebral blood flow changes as an important component of sleep were first considered by Hill. ${ }^{15}$ Mangold et al.$^{16}$ found a rise in CBF when subjects passed into sleep. Prinz et al. ${ }^{17}$ using xenon-clearance techniques, found that subjects had, compared with when awake, a higher CBF in REM sleep, but a lower one in nonREM. Milligan (D Milligan, 1979, personal communication) measuring jugular flow uncorrected for vertebral leakage, found consistently lower values in nonREM than REM sleep.

Department of Medicine, Royal Alexandra Hospital for Children, Camperdown, New South Wales, Australia P M RAHILLY, neonatologist
The effects of feeding on cerebral blood flow were first considered by Bayliss and Hill ${ }^{18}$ who postulated in-balance between splanchnic and cranial flow. Changes in the general circulation in the adult have been investigated extensively. ${ }^{19-22}$ There have also been studies in the newborn. ${ }^{23-24}$ The results of these various studies were contradictory but tended to indicate a rise in cardiac output after feeds with a fall in peripheral flow. Rowe et al..$^{25}$ found no change in the CBF of adults after a meal. In neonates however, studies using a zero-gradient ear thermometer ${ }^{26-27}$ and vertex thermography ${ }^{28}$ indicated a rise in cranial temperature after feeds (possibly caused by a fall in the cooling arterial flow). Recently, Dear ${ }^{39}$ demonstrated a consistently lower jugular flow during the first $\mathbf{3 0}$ minutes after a feed. His study did not take full account of sleep states, and as 'food soothes the nervous system of a child'29 and lulls a child into sleep, it must be considered incomplete.

Studies of the effects of sleep (D Milligan, 1979, personal communication) and feeds ${ }^{39}$ on jugular flow, as well as studies on the effects of $\mathrm{CO}_{2}$ and $100 \% \mathrm{O}_{2}{ }^{40}$ indicate that the neonate has a highly labile CBF. For this reason the work presented here includes blood pressure studies during different sleep states in an attempt to test the autonomy of the CBF.

\section{Method}

The technique and analysis used were as previously described..$^{2-3}$ A mercury-in-Silastic strain gauge was placed round the head of a sleeping infant. This was 
connected via a Wheatstone bridge to a HewlettPackard recording system which traced the changes in head circumference caused by heart beat and jugular occlusion. To analyse the compressions, exponentials were fitted by computer program (BMDP3R) ${ }^{30}$ Jugular flow was derived by calculating the differential at time zero on the inflow curve. 'Vertebral' flow (that is, flow down the noncompressible pathways) was calculated by comparing the rate constants of the inflow and outflow curves. The mathematics of this correction factor was based on a mathematical model which compared the head to an electrical capacitor.

The final formula is:

$\mathrm{Fc}=\mathrm{A} \mathrm{Li} \quad \frac{\mathrm{Lo}}{\mathrm{Lo}-\mathrm{Li}}$

Where $\mathrm{Fc}=$ cranial blood flow $\mathrm{A}=$ height of plateau on inflow curve $\mathrm{Li}=$ rate constant for inflow curve Lo $=$ rate constant for outflow curve.

Each result was obtained from a set of 10 compressions, the values being $\pm \mathrm{SE}$ and mean.

Sleep state was monitored clinically and by EEG using biparietal discs (D Milligan, 1979, personal communication). The classification divides sleep into four states:

(1) REM, (2) transitional, (3) nonREM, (4) nonREM with trace alternans.

In the results sections stage 2 is excluded, and stages 3 and 4 are combined.

Blood pressure was monitored using a standard neonatal cuff, systolic end-point being detected with a Parks Doppler (model 801-B), the probe being placed on the brachial artery. All the babies were born in the maternity wards of The London Hospital
(Whitechapel) and were term and healthy. The mothers were chosen by the nursing staff and the purpose of the trials was fully explained to each of them. In all cases mothers were present for the studies and many of them became closely connected with the work.

Sleep study. 20 babies (mean age $98 \cdot 3$ hours, range 38-180; mean weight $3047 \cdot 5 \mathrm{~g}$, range $2000-3800$ ) had their CBF measured in stage 1 (REM) and in stages 3-4 (nonREM) sleep. For each baby, these measurements were taken at one session (within 3 hours of each other at the most) with the baby under the same conditions (including posture) and at least 30 minutes after the last feed. Seven of these 20 babies had each set of compressions bracketed by blood pressure readings before and afterwards.

Feeding study. A series of CBF measurements was made on 25 babies. Each measurement was taken at a known time after the last feed, and while the baby was in a recognisable sleep state. Each series was performed at the same session, usually taking 3-4 hours. It was not possible to take these measurements at fixed postprandial times as during a 4-hour session the sleep states would vary greatly. Of these 25 babies only 13 produced a series of readings taken in comparable sleep states (mean age 103.8 hours, range 38-342; mean weight $3397 \mathrm{~g}$, range 2850-4006).

11 of these 13 babies were breast fed. In 9 of these it was possible to 'test weigh' the babies before and after the feed. In addition, 17 bottle-fed babies (most of whom were not in the CBF trial) were 'test

Table 1 Effects of sleep stages (cranial blood flow $\mathrm{ml} / \mathrm{min}$ per $100 \mathrm{~g}$ )

\begin{tabular}{|c|c|c|c|c|c|c|c|c|}
\hline \multirow[t]{2}{*}{ Case } & \multicolumn{4}{|c|}{ Sleep stage 1 (REM) } & \multicolumn{4}{|c|}{ Sleep stages 3-4 (nonREM) } \\
\hline & Total & Jugular & Vertebral & $\%$ vertebral & Total & Jugular & Vertebral & $\%$ vertebral \\
\hline $\begin{array}{r}9 \\
22 \\
33 \\
39 \\
40 \\
42 \\
45 \\
46 \\
50 \\
51 \\
56 \\
57 \\
67 \\
90 \\
91 \\
92 \\
93 \\
94 \\
97 \\
98\end{array}$ & $\begin{array}{r}36.2 \pm 3.1 \\
37.8 \pm 2.9 \\
31.0 \pm 4.0 \\
38.4 \pm 3.0 \\
30.0 \pm 2.0 \\
53.0 \pm 2.0 \\
52.0 \pm 3.0 \\
24.0 \pm 2.0 \\
118.0 \pm 4.1 \\
40.8 \pm 2.0 \\
21.0 \pm 0.9 \\
30.1 \pm 2.0 \\
63.1 \pm 3.0 \\
22.2 \pm 1.0 \\
31.8 \pm 3.0 \\
21.7 \pm 1.0 \\
29.3 \pm 1.0 \\
47.2 \pm 2.4 \\
28.25 \pm 1.6 \\
44.9 \pm 1.2\end{array}$ & 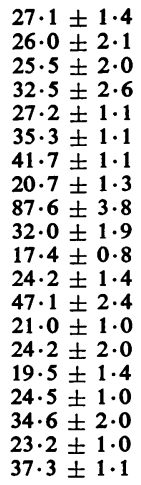 & $\begin{array}{c}9 \cdot 1 \\
11 \cdot 8 \\
5 \cdot 5 \\
5 \cdot 9 \\
2 \cdot 8 \\
17 \cdot 5 \\
10 \cdot 3 \\
3 \cdot 3 \\
30 \cdot 4 \\
8 \cdot 8 \\
3 \cdot 6 \\
5 \cdot 9 \\
16 \cdot 0 \\
1 \cdot 2 \\
7 \cdot 6 \\
2 \cdot 2 \\
4 \cdot 8 \\
12 \cdot 6 \\
5 \cdot 05 \\
7 \cdot 6\end{array}$ & $\begin{array}{r}25 \cdot 0 \\
31 \cdot 2 \\
17 \cdot 7 \\
15 \cdot 3 \\
9 \cdot 3 \\
33 \cdot 0 \\
19 \cdot 8 \\
13 \cdot 8 \\
25 \cdot 8 \\
21 \cdot 5 \\
17 \cdot 1 \\
19 \cdot 6 \\
25 \cdot 4 \\
5 \cdot 4 \\
23 \cdot 8 \\
10 \cdot 1 \\
16 \cdot 4 \\
26 \cdot 7 \\
17 \cdot 9 \\
17 \cdot 0\end{array}$ & $\begin{array}{r}23.4 \pm 2.7 \\
33.4 \pm 2.4 \\
28.0 \pm 3.0 \\
34.0 \pm 2.0 \\
27.0 \pm 1.4 \\
51.0 \pm 1.8 \\
47.0 \pm 2.8 \\
22.0 \pm 2.0 \\
102.0 \pm 3.7 \\
30.0 \pm 2.4 \\
19.1 \pm 0.6 \\
23.4 \pm 2.0 \\
40.8 \pm 3.0 \\
17.6 \pm 1.0 \\
28.3 \pm 3.0 \\
18.2 \pm 1.4 \\
20.9 \pm 1.0 \\
27.8 \pm 1.2 \\
20.4 \pm 0.9 \\
30.7 \pm 1.3\end{array}$ & $\begin{array}{l}18.8 \pm 1.0 \\
24.1 \pm 1.2 \\
19.6 \pm 2.1 \\
28.4 \pm 1.7 \\
24.2 \pm 1.1 \\
31.8 \pm 2.0 \\
38.3 \pm 2.1 \\
17.8 \pm 1.4 \\
76.1 \pm 6.4 \\
24.5 \pm 2.5 \\
16.6 \pm 1.0 \\
19.7 \pm 1.1 \\
33.4 \pm 2.1 \\
16.5 \pm 1.0 \\
19.2 \pm 1.4 \\
16.6 \pm 1.1 \\
18.8 \pm 1.2 \\
23.7 \pm 1.4 \\
17.9 \pm 0.7 \\
24.4 \pm 0.7\end{array}$ & $\begin{array}{c}4 \cdot 6 \\
9 \cdot 3 \\
8 \cdot 4 \\
5 \cdot 6 \\
2 \cdot 8 \\
19 \cdot 2 \\
8 \cdot 7 \\
4 \cdot 2 \\
25 \cdot 9 \\
5 \cdot 5 \\
2 \cdot 5 \\
3 \cdot 65 \\
7 \cdot 4 \\
1 \cdot 1 \\
9 \cdot 1 \\
2 \cdot 2 \\
2 \cdot 1 \\
4 \cdot 1 \\
2 \cdot 5 \\
6 \cdot 3\end{array}$ & $\begin{array}{l}19 \cdot 6 \\
28 \cdot 0 \\
30 \cdot 0 \\
16 \cdot 5 \\
10 \cdot 3 \\
37 \cdot 6 \\
18 \cdot 5 \\
19 \cdot 1 \\
25 \cdot 5 \\
18 \cdot 3 \\
13 \cdot 1 \\
15 \cdot 6 \\
18 \cdot 1 \\
6 \cdot 2 \\
32 \cdot 1 \\
12 \cdot 0 \\
10 \cdot 0 \\
14 \cdot 7 \\
12 \cdot 3 \\
20 \cdot 0\end{array}$ \\
\hline Mean & $40 \cdot 0 \pm 4.8$ & $31.4 \pm 3.4$ & $8 \cdot 5 \pm 1 \cdot 5$ & $19.6 \pm 1.6$ & $32 \cdot 2 \pm 4 \cdot 2$ & $25.5 \pm 3.0$ & $6.8 \pm 1 \cdot 3$ & $18.9 \pm 1.8$ \\
\hline
\end{tabular}


Table 2 Effects of sleep state on cranial blood flow comparing stage 1 (REM) with stages 3-4 (nonREM) sleep in 20 babies

\begin{tabular}{lcccl}
\hline & Total & Jugular & Vertebral & $\%$ vertebral \\
\hline Mean rise (ml/min & & & & \\
$\quad$ per $100 \mathrm{~g})$ & 7.8 & 5.9 & 1.7 & 0.7 \\
Mean rise (\%) & 24.2 & 23.0 & 25.0 & 3.6 \\
Range rise (\%) & 69.8 to & 50 to & 97.8 to & 81 to \\
& 9.5 & 14.2 & -34 & -41 \\
Paired $t$ & 5.813 & 6.484 & 2.716 & 0.796 \\
P & $<0.001$ & $<0.001$ & $<0.025$ & NS \\
\hline
\end{tabular}

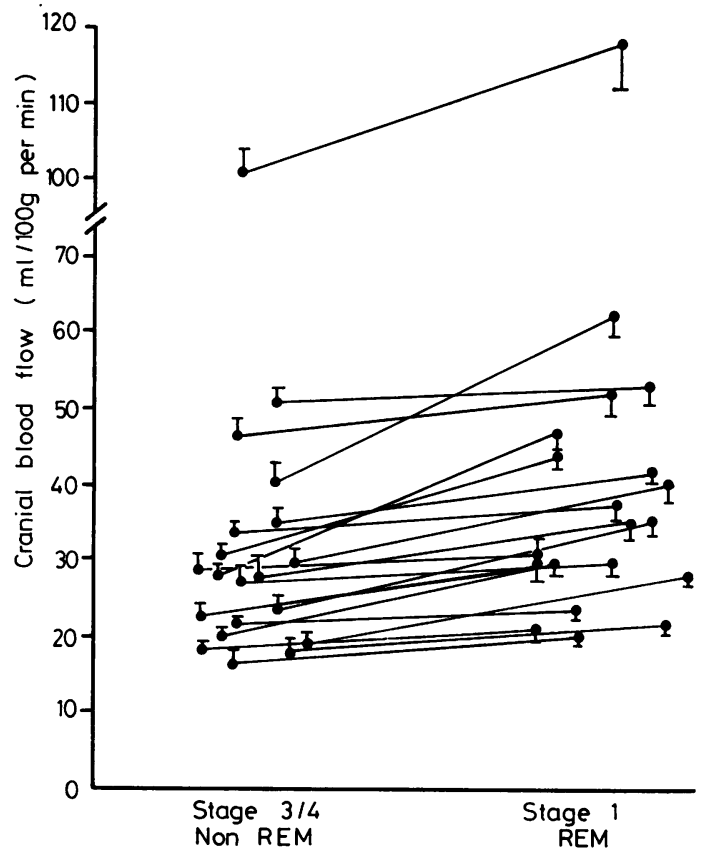

Fig. 1 Changes in cranial flow of 20 babies in different sleep states (bars show SE). Points are staggered for clarity of presentation. Range of change $19 \cdot 5-69 \cdot 8 \%$ (mean 24.2\%, $P<0.001$ ). weighed' and the volume of feed taken from the bottle noted by an independent observer. The babies were kept fully clothed so that faeces and urine collected in the nappy were not lost from total weight.

\section{Results}

Sleep studies. The results from 20 babies are shown in Table 1 and summarised in Table 2. CBF was consistently higher in REM than in nonREM sleep (Fig. 1). The mean difference was $24 \cdot 2 \%$ which is significant $(P<0.001)$. With the increased total flow in REM there was also an increase in the vertebral percentage. Although this rise was in absolute terms insignificant, the rise in vertebral percentage had a significant correlation with the rise in total CBF $(r=0.734, P<0.01)$. In other words, when the total flow rises by more than about $20 \%$ the extra drainage is mostly provided by the vertebral system.

The direction of sleep state change did not affect the degree of changes in CBF. In 9 babies passing from REM to nonREM the mean percentage difference was $22 \cdot 2 \%(\mathrm{SE}=5 \cdot 6)$. When the change was the other way round the mean percentage change was $29 \cdot 3 \%(\mathrm{SE}=7 \cdot 1)$.

The results of the blood pressure study are shown in Table 3.

Systolic blood pressure was consistently higher in REM than in nonREM sleep (mean difference $20 \cdot 2 \%, \mathrm{P}<0.001$ by paired Student's $t$ test). There was, however, no correlation between blood pressure and CBF in the individual babies in REM or nonREM. Nor was there any correlation between the degree of the change in CBF and changes in BP brought about by alterations in sleep state in the individual babies.

Feeding studies. The results from the 'test weighing' assessment are shown in Fig. 2. There is an extremely close correlation showing that when performed with care this is an accurate measurement of the amount of feed taken by a baby.

Table 3 Cranial blood flow ( $\mathrm{ml} / \mathrm{min}$ per $100 \mathrm{~g}$ ), sleep states, and systolic blood pressure (BP)

\begin{tabular}{|c|c|c|c|c|c|c|c|c|}
\hline \multirow[t]{2}{*}{ Case } & \multicolumn{4}{|c|}{ Sleep stage 1 (REM) } & \multicolumn{4}{|c|}{ Sleep stages 3-4 (nonREM) } \\
\hline & Ist $B P$ & 2nd $B P$ & Mean $B P$ & Cranial flow & 1st $B P$ & 2nd $B P$ & Mean $B P$ & Cranial flow \\
\hline $\begin{array}{l}90 \\
91 \\
92 \\
93 \\
94 \\
95^{*} \\
97 \\
98 \\
99\end{array}$ & $\begin{array}{r}70 \\
81 \\
85 \\
86 \\
81 \\
98 \\
106 \\
92 \\
96\end{array}$ & $\begin{array}{r}72 \\
80 \\
85 \\
90 \\
83 \\
100 \\
110 \\
94 \\
98\end{array}$ & $\begin{array}{c}71 \\
80 \cdot 5 \\
85 \\
88 \\
82 \\
99 \\
108 \\
93 \\
97\end{array}$ & $\begin{array}{r}22.20 \pm 1 \\
31.80 \pm 3 \\
21.70 \pm 1 \\
29.30 \pm 1 \\
47.20 \pm 2.4 \\
8.00 \pm 0.6 \\
28.25 \pm 1.6 \\
44.90 \pm 1.1 \\
32.50 \pm 1.5\end{array}$ & $\begin{array}{l}56 \\
69 \\
70 \\
78 \\
68 \\
84 \\
? \\
78 \\
-\end{array}$ & $\begin{array}{l}57 \\
70 \\
68 \\
76 \\
68 \\
84 \\
92 \\
78 \\
-\end{array}$ & $\begin{array}{l}56 \cdot 5 \\
69 \cdot 5 \\
69 \\
77 \\
68 \\
84 \\
92 \\
78 \\
-\end{array}$ & $\begin{array}{c}17.60 \pm 1 \\
28.30 \pm 3 \\
18.20 \pm 9 \\
20.90 \pm 1 \\
27.80 \pm 1.2 \\
3.77 \pm 1 \\
20.40 \pm 0.9 \\
30.70 \pm 0.9 \\
-\end{array}$ \\
\hline
\end{tabular}

*Overriding sutures. 1st BP before set of compression waves, 2nd BP after set of compression waves. 


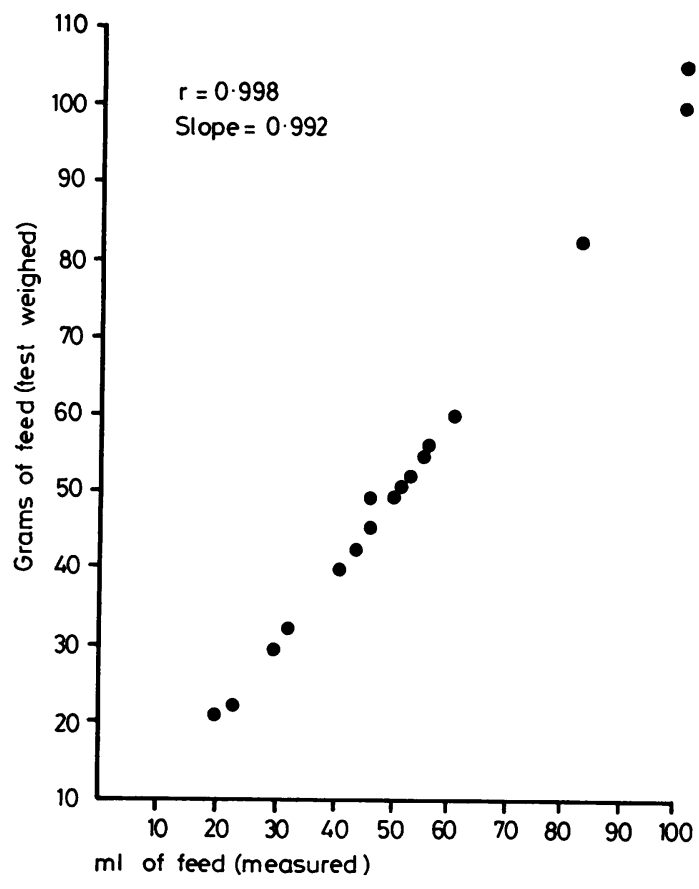

Fig. 2 Close correlation between volume of milk given from a bottle and weight of the feed as measured by test weighing 17 different babies $(r=0.998)$.

The CBF results from the 13 babies are shown in Table 4 and summarised in Table 5. There is a consistently lower CBF in the first hour after a feed (Fig. 3) than in the 'resting' period of at least 2 hours after a feed. The mean difference $(34.5 \%)$ is significant $(P<0.005)$. In those 5 babies in whom readings were available for the first 30 minutes after a feed the mean difference $(31.4 \%)$ is also significant $(P<0 \cdot 05)$. The readings taken during the 60- to 120-minute period show a variable recovery pattern since the postprandial fall.

There was no correlation between the volume of feed given and the changes in CBF caused by the feed ( $r=0.414$ in 10 babies).

\section{Discussion}

The mean difference in CBF (24.2\%) found in REM and nonREM is similar to that found in jugular flow ( $23 \%$ ) by Milligan (D Milligan, 1979, personal communication). These differences emphasise the importance of knowing the sleep state of a baby during any CBF studies.

The absolute values of systolic blood pressure are in keeping with previous work. $^{31-32}$ The lack of correlation between either absolute values or changes in blood pressure and CBF argue against the autonomy of the CBF being poorly developed in this age group, whatever the sleep state.

The lower CBF found during the first hour after a feed agrees with the findings of Dear. ${ }^{39}$ The variability of the recovery pattern emphasises the importance of taking sleep state into account. Babies were quite often in nonREM sleep for much of the first hour after a feed and in REM sleep for the second, hence the rather high exclusion rate from this study.

The possible causes of this fall have been discussed by Dear. ${ }^{39}$ The concept of Yao et $a .^{23}$ of the low pressure, low resistance, high output circulation of the neonate, rendering it unable to compensate for a sudden increase in splanchnic flow is not supported by the blood pressure studies. Another possibility is a metabolic cause for these changes. The rise in metabolics, such as ketones, ${ }^{33-34}$ which are taken up by the newborn's brain ${ }^{35}$ might activate some complex negative feedback system.

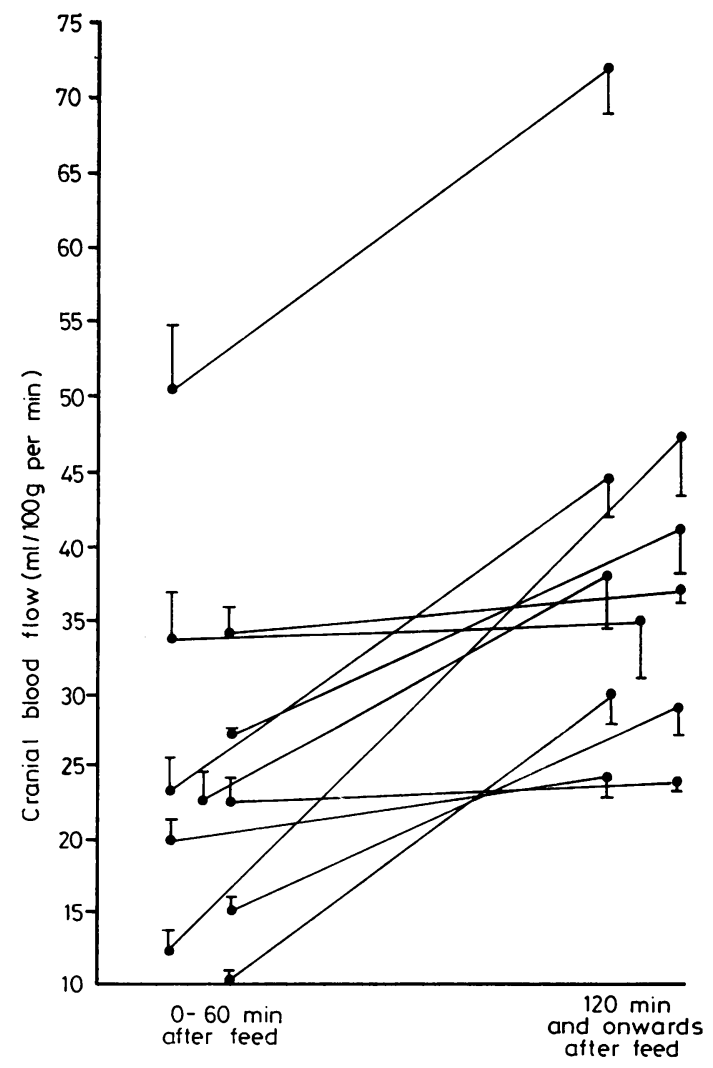

Fig. 3 Change in cranial blood flow of 11 babies after feeding. Mean fall after feed $34.5 \%, P<0.001$, range $8-65 \%$ (each baby was in a constant sleep state). 
Table 4 Effects of feeding (cranial blood flow, ml/100 g per min + SE) pooled in hourly intervals

\begin{tabular}{|c|c|c|c|c|c|c|c|c|c|c|c|}
\hline \multirow[t]{3}{*}{ Case } & \multirow{3}{*}{$\begin{array}{l}\text { Sleep } \\
\text { stage }\end{array}$} & \multirow{3}{*}{$\begin{array}{l}\text { Feed } \\
(\mathrm{ml} / \mathrm{kg})\end{array}$} & \multicolumn{9}{|l|}{ After feed } \\
\hline & & & \multicolumn{3}{|l|}{$0-60 \min$} & \multicolumn{3}{|l|}{$60-120 \mathrm{~min}$} & \multicolumn{3}{|l|}{$120+\min$} \\
\hline & & & $\begin{array}{l}\text { Cranial } \\
\text { blood flow }\end{array}$ & $S E$ & $\begin{array}{l}\text { Time after } \\
\text { feed (min) }\end{array}$ & $\begin{array}{l}\text { Cranial } \\
\text { blood flow }\end{array}$ & $S E$ & $\begin{array}{l}\text { Time after } \\
\text { feed (min) }\end{array}$ & $\begin{array}{l}\text { Cranial } \\
\text { blood flow }\end{array}$ & $S E$ & $\begin{array}{l}\text { Time after } \\
\text { feed (min) }\end{array}$ \\
\hline 29 & 1 & $\begin{array}{l}\text { Bottle } \\
22 \cdot 6\end{array}$ & $\begin{array}{l}26 \cdot 6 \\
19 \cdot 9 \\
23 \cdot 2\end{array}$ & $\begin{array}{l}1 \cdot 4 \\
2 \cdot 7 \\
2 \cdot 1\end{array}$ & $\begin{array}{l}12 \\
47 \\
\text { Mean }\end{array}$ & $12 \cdot 1$ & $1 \cdot 0$ & 75 & $45 \cdot 2$ & $3 \cdot 1$ & 210 \\
\hline 31 & 1 & $\begin{array}{l}\text { Breast } \\
25 \cdot 0\end{array}$ & $13 \cdot 0$ & $1 \cdot 0$ & 26 & $37 \cdot 0$ & $3 \cdot 0$ & 65 & $\begin{array}{l}37 \cdot 0 \\
58 \cdot 0 \\
47 \cdot 5 \\
32 \cdot 0\end{array}$ & $\begin{array}{l}4 \cdot 0 \\
4 \cdot 0 \\
1 \cdot 8 \\
2 \cdot 0\end{array}$ & $\begin{array}{l}130 \\
160 \\
\text { Mean } \\
150\end{array}$ \\
\hline 39 & 1 & $\begin{array}{l}\text { Breast } \\
4 \cdot 1\end{array}$ & $33 \cdot 7$ & $3 \cdot 0$ & 27 & & & & $\begin{array}{l}38 \cdot 4 \\
35 \cdot 2\end{array}$ & $\begin{array}{l}3 \cdot 0 \\
4 \cdot 0\end{array}$ & $\begin{array}{l}210 \\
\text { Mean }\end{array}$ \\
\hline 45 & 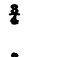 & $\begin{array}{l}\text { Breast } \\
8 \cdot 7\end{array}$ & $34 \cdot 0$ & $1 \cdot 8$ & 50 & $47 \cdot 0$ & $3 \cdot 0$ & 100 & $37 \cdot 0$ & $1 \cdot 2$ & 130 \\
\hline 48 & $\frac{3}{4}$ & $\begin{array}{l}\text { Breast } \\
15 \cdot 0\end{array}$ & $15 \cdot 2$ & $1 \cdot 0$ & 35 & $23 \cdot 4$ & $2 \cdot 0$ & 90 & 29.0 & $2 \cdot 5$ & 125 \\
\hline 54 & 1 & $\begin{array}{l}\text { Breast } \\
6.5\end{array}$ & $22 \cdot 6$ & $1 \cdot 5$ & 25 & $32 \cdot 9$ & $1 \cdot 0$ & 75 & $23 \cdot 6$ & $0 \cdot 2$ & 125 \\
\hline 57 & 1 & $\begin{array}{l}\text { Breast } \\
19.7\end{array}$ & $20 \cdot 1$ & $1 \cdot 7$ & 55 & $29 \cdot 8$ & $2 \cdot 0$ & 90 & $24 \cdot 0$ & $1 \cdot 0$ & 125 \\
\hline 67 & 8 & $\begin{array}{l}\text { Breast } \\
6 \cdot 7\end{array}$ & $25 \cdot 8$ & 0.8 & 55 & & & & $41 \cdot 0$ & $2 \cdot 7$ & 240 \\
\hline 68 & 1 & $\begin{array}{l}\text { Breast } \\
25 \cdot 0\end{array}$ & $50 \cdot 1$ & $5 \cdot 0$ & 35 & & & & $72 \cdot 0$ & $3 \cdot 0$ & 135 \\
\hline 70 & $\frac{8}{8}$ & Breast & $10 \cdot 6$ & $0 \cdot 7$ & 45 & & & & $29 \cdot 8$ & $2 \cdot 0$ & 175 \\
\hline 74 & $\frac{8}{8}$ & $\begin{array}{l}\text { Breast } \\
10 \cdot 2\end{array}$ & $24 \cdot 7$ & $2 \cdot 0$ & 25 & & & & $38 \cdot 0$ & $3 \cdot 5$ & 135 \\
\hline 55 & 1 & $\begin{array}{l}\text { Breast } \\
5 \cdot 7\end{array}$ & $23 \cdot 7$ & $3 \cdot 0$ & 45 & $23 \cdot 1$ & $2 \cdot 0$ & 75 & & & \\
\hline 64 & $\frac{8}{7}$ & $\begin{array}{l}\text { Bottle } \\
11 \cdot 3\end{array}$ & 29.9 & $2 \cdot 0$ & 35 & $22 \cdot 4$ & $2 \cdot 0$ & 85 & & & \\
\hline \multicolumn{3}{|c|}{ Overall mean } & $25 \cdot 1$ & $3 \cdot 0$ & 37 & $28 \cdot 3$ & $3 \cdot 0$ & 82 & $38 \cdot 3$ & $4 \cdot 0$ & 158 \\
\hline
\end{tabular}

Table 5 Effects of feeding on cranial blood flow, comparisons between the three time periods combined (each baby in constant sleep state)

\begin{tabular}{|c|c|c|c|}
\hline & $A / B$ & $B / C$ & $A / C$ \\
\hline $\begin{array}{l}\text { No. of babies } \\
\text { Mean fall after feed } \\
\quad(\mathrm{ml} / 100 \mathrm{~g} \text { per } \mathrm{min})\end{array}$ & ${ }_{3 \cdot 2}^{8}$ & $\begin{array}{r}6 \\
10\end{array}$ & $\begin{array}{l}11 \\
13 \cdot 2\end{array}$ \\
\hline $\begin{array}{l}\text { Fall after feed }(\%) \\
\text { Range of } \% \text { fall in paired }\end{array}$ & $11 \cdot 3$ & $26 \cdot 1$ & $34 \cdot 5$ \\
\hline $\begin{array}{l}\text { babies } \\
\text { Paired } t \\
\mathbf{P}\end{array}$ & $\begin{array}{l}64 \cdot 8 \text { to }-83 \\
1.427 \\
\text { NS }\end{array}$ & $\begin{array}{l}73 \text { to }-43 \cdot 4 \\
0 \cdot 627 \\
\text { NS }\end{array}$ & $\begin{array}{r}8 \text { to } 65 \\
4 \cdot 224 \\
<0.005\end{array}$ \\
\hline
\end{tabular}

A 0-60 $\mathrm{min}$ after feed, B 60-120 $\mathrm{min}$ after feed, C $120 \mathrm{~min}$ onwards.

On each occasion the later of the postprandial readings is used as the basis for comparison.

A metabolic cause would also explain the variability of the responses to feeding and the poor correlation of the degrees of change with the amounts of feed taken. The metabolic response of the newborn is known to alter with nutritional state. ${ }^{36}$ These babies, most of whom were breast fed, could be expected to have a varied nutritional state, particularly as all but one were under 2 weeks old. Again, the composition of breast milk varies greatly from mother to mother, and even in the same mother within feeds, ${ }^{37}$ so that correlation between amount of feed and actual metabolic load could be expected to be poor.

The feeds taken by these babies were, on a weight basis, similar to those given to premature babies in many units (say $200 \mathrm{ml} / \mathrm{kg}$ per 24 hours in 12 2-hourly feeds). Bolus feeding regimens could therefore, be causing quite substantial fluctuations in the premature baby. These fluctuations could, in turn, be predisposing the sick, acidotic premature infants to intraventricular haemorrhage. ${ }^{38}$

I thank Professor K W Cross for guidance with this work, Dr Ian Stothers for constructive criticism, Mr Tony Barnett and Mr Ron Shew who built the electrical and mechanical components of the apparatus, and Mrs Stella Legge, research nurse, who assisted at every measurement.

\section{References}

1 Cross K W, Dear P R F, Warner R M, Watling G B. An attempt to measure cerebral blood-flow in the newborn infant. J Physiol (Lond) 1976; 260 : 42-3P. 
${ }^{2}$ Cross K W, Dear P R F, Hathorn M K S, et al. An estimation of intracranial blood flow in the newborn infant. J Physiol (Lond) 1979; 289 : 329-45.

${ }^{3}$ Cross K W, Kerslake D Mc K, Rahilly P M. The ratio of cranial to jugular blood flow in the newborn. $J$ Physiol (Lond) 1978; 280: 62-3P.

4 Snyder F, Hobson J A, Morrison D F, Goldfrank F. Changes in respiration, heart rate, and systolic blood pressure in human sleep. $J$ Appl Physiol 1964; 19 : 417-22.

5 Jouvet M. The states of sleep. Sci Am 1967; 216: 62-72.

- Davis H, Davis P A, Loomis A L, Harvey E M, Hobart G. Human brain potentials during the onset of sleep. $J$ Neurophysiol 1938; 1: 24-38.

7 Aserinsky E, Kleitman N. Regularly occurring periods of eye motility and concomitant phenomena during sleep. Science 1953; 118: 273-4.

8 Aserinsky E, Kleitman N. A motility cycle in sleeping infants as manifested by ocular and gross bodily activity. J Appl Physiol 1955; 8: 11-18.

- Aserinsky E, Kleitman N. Two types of ocular motility occurring in sleep.J Appl Physiol 1955; 8: 1-10.

10 Dement W, Kleitman N. Cyclic variations in EEG during sleep and their relation to eye movements, body motility, and dreaming. Electroencephalogr Clin Neurophysiol 1957; 9: 673-90.

11 Dreyfus-Brisac C, Monod N. Sleep of premature and full-term neonates. A polygraphic study. Proc $R$ Soc Med $1965 ; 58: 6-7$.

12 Roffwarg H P, Muzio J N, Dement W C. Ontogenic development of human sleep-dream cycle. Science 1966; 152: 604-19.

13 Dawes G S, Fox H E, Leduc B M, Liggins G C, Richards $R$ T. Respiratory movements and rapid eye movement sleep in the foetal lamb. J Physiol (Lond) 1972; 220: 119-43.

14 Dittrichová J. Nature of sleep in young infants. J Appl Physiol 1962;17: 543-6.

15 Hill L. Arterial pressure in man while sleeping, resting, working, and bathing. J Physiol (Lond) 1898; 22: $26-9$.

16 Mangold R, Sokoloff L, Conner E, Kleinerman J, Therman P G, Kety S S. The effects of sleep and lack of sleep on the cerebral circulation and metabolism of normal young men. J Clin Invest 1955; 34: 1092-100.

17 Prinz P N, Townsend R E, Obrist W D. Human cerebral blood flow during sleep and waking. Psychophysiology 1971; 9: 106 .

18 Bayliss W M, Hill L. On intra-cranial pressure and the cerebral circulation. I. Physiological. J Physiol (Lond) 1895; 18: 334-60.

19 Collet M E, Liljestrand G. Variations in the resting minute volume of the heart in man. Skand Arch Physiol 1924; 45: 17-28.

20 Abramson D I, Fierst S M. Peripheral vascular responses in man during digestion. Am J Physiol 1941; 133: 686-93.

21 Booth G, Strang J M. Changes in the temperature of the skin following the ingestion of food. Arch Intern Med 1936; 57: 533-43.

22 Reininger E J, Sapirstein L A. Effect of digestion on distribution of blood flow in the rat. Science 1957; 126: 1176.

23 Yao A C, Wallgren C G, Sinha S N, Lind J. Peripheral circulatory response to feeding in the newborn infant. Pediatrics 1971 ; 47: 378-83.

24 Gupta J M, Scopes J W. Observations on blood pressure in newborn infants. Arch Dis Child 1965; 40: 637-44.
25 Rowe G G, Maxwell G M, Castillo C A, Freeman D J, Crumpton C W. A study in man of cerebral blood flow and cerebral glucose, lactate, and pyruvate metabolism before and after eating. $J$ Clin Invest $1959 ; 38: 2154-8$.

26 Cross K W, Stothers J K, Stratton D. An indirect estimate of total brain energy metabolism in the newborn infant. J Physiol (Lond) 1975; 250: 15-6P.

27 Stratton D. Aural temperature of the newborn infant. Arch Dis Child 1977; 52: 865-9.

28 Cross K W, Stothers J K, Warner R M, Woodrough R W. The application of thermography to the detection of energy metabolism of the brain in the newborn infant. J Physiol (Lond) 1975; 252: 44-5P.

29 Murlin J R, Conklin R E, Marsh E M. Energy metabolism of normal newborn babies. Am J Dis Child 1925; 29: 1-28.

30 Dixon W J. BMD manual P3R. Los Angeles: University of California, 1975.

31 Moss A J, Duffie E R, Jr, Emmanouilides G. Blood pressure and vasomotor reflexes in the newborn infant. Pediatrics 1963; 32: 175-9.

32 Shinebourne E A. Growth and development of the cardiovascular system: functional development. In: Davis J A, Dobbing J, eds. Scientific foundations of paediatrics. London: Heinemann Medical, 1974: 203.

33 Gentz J, Kellum M, Persson B. The effects of feeding on oxygen consumption and plasma levels of glucose, FFA, and D- $\beta$-hydroxybutarate in newborn infants of diabetic mothers and small for gestational age infants. Acta Paediatr Scand 1976; 65: 445-54.

34 Lucas A, Bloom S R, Aynsley-Green A. Metabolic and endocrine events at the time of the first feed of human milk in preterm and term infants. Arch Dis Child 1978; 53: 731-6.

35 Settergren G, Lindblad B S, Persson B. Cerebral blood flow and exchange of oxygen, glucose, ketone bodies, lactate pyruvate, and amino acids in infants. Acta Paediatr Scand 1976; 65: 343-53.

36 Gentz J, Bengtsson G, Hakkarainen J, Hellström R, Persson B. Factors influencing oxygen consumption in the newborn pig, with special reference to feeding. Biol Neonate 1970; 16: 328-41.

37 Mackeith R C, Wood C. In: Infant feeding and feeding difficulties. London: Churchill Livingstone, 1977: 71.

38 Hambleton G, Wigglesworth J S. Origin of intraventricular haemorrhage in the preterm infant. Arch Dis Child 1976; 51: 651-9.

39 Dear P R F. Effect of feeding on jugular venous blood flow in the normal newborn infant. Arch Dis Child 1980; 55: 365-70.

40 Rahilly P M. The effect of $2 \% \mathrm{CO}_{2}, 0.5 \% \mathrm{CO}_{2}$, and $100 \% \mathrm{O}_{2}$ on the cranial blood flow of the human neonate. Pediatrics 1979; in press.

41 Monod N, Pajot N. Le sommeil du nouveau-né et du premature. Biol Neonate $1965 ; 8$ : 281-307.

427 Monod N, Curzi-Dascalova L. Les etats transitionnels de sommeil chez le nouveau-né a terme. Rev Electroencephalogr Neurophysiol Clin 1 73; 3: 87-96.

Correspondence to Dr P M Rahilly, Department of Medicine, Royal Alexandra Hospital for Children, PO Box 34, Pyrmont Bridge Road, Camperdown, New South Wales 2050, Australia.

Recieved 8 March 1979 